JOTE Volume 2 Nomor 1 Tahun 2020 Halaman 167-176 JOURNAL ON TEACHER EDUCATION Research \& Learning in Faculty of Education

\title{
PENERAPAN TEKNIK MODELING UNTUK MENINGKATKAN KEMAMPUAN BERBICARA BAHASA INDONESIA DALAM MENY AMPAIKAN PIDATO PERSUASIF DI KELAS IXA SMP NEGERI 1 MEGO
}

\author{
Gabriel Frans Posenti Renu Tiang ${ }^{1}$ \\ SMP Negeri 1 Mego, Sikka, Nusa Tenggara Timur \\ Email: gabrielposenti2@gmail.com
}

\begin{abstract}
Abstrak
Penelitian ini bertujuan untuk meningkatkan kemampuan berbicara bahasa Indonesia dalam menyampaikan pidato persuasif melalui teknik modeling di kelas IXA SMP Negeri 1 Mego. Penelitian ini merupakan penelitian kualitatif. Data penelitian diambil dari aktivitas guru dan aktivitas siswa. Teknik pengumpulan data dalam penelitian ini adalah observasi, wawancara, dan dokumentasi. Analisis data dilaksanakan dengan mengamati aktivitas guru dan siswa dalam melaksanakan proses pembelajaran dengan menggunakan teknik modeling. Penelitian ini dilaksanakan dalam dua kali pertemuan yaitu pertemuan I dan pertemuan II. Hasil penelitian menunjukkan bahwa proses penerapan teknik modeling dalam pembelajaran membuat siswa lebih bersemangat dan sangat antusias. Hasil penelitian menunjukkan bahwa penerapan teknik modeling dapat meningkatkan kemampuan berbicara bahasa Indonesia dalam menyampaikan pidato persuasif di kelas IXA SMP Negeri 1 Mego
\end{abstract}

Kata kunci: kemampaun berbicara, pidato persuasif, modeling

\begin{abstract}
ability to speak Indonesian in delivering persuasive speeches through modeling techniques in class IXA SMP Negeri 1 Mego. This research is a qualitative research. The research data were taken from teacher activities and student activities. Data collection techniques in this study were observation, interviews, and documentation. Data analysis was carried out by observing the activities of teachers and students in carrying out the learning process using modeling techniques. This research was conducted in two meetings, namely meeting I and meeting II. The results showed that the process of applying modeling techniques in learning made students more excited and very enthusiastic. The results showed that the application of modeling techniques can improve the ability to speak Indonesian in delivering persuasive speeches in class IXA SMP Negeri 1 Mego.
\end{abstract}

Keywords: speaking skills, persuasive speech, modeling 


\section{PENDAHULUAN}

Bahasa Indonesia merupakan mata pelajaran yang membahas di dalamnya meliputi keterampilan menyimak, mendengar, berbicara, membaca, dan menulis. Keterampilan berbicara merupakan salah satu komponen dalm pembelajaran bahasa Indonesia yang harus dimiliki oleh pendidik dan peserta didik di sekolah. Terampil berbicara menuntut siswa untuk dapat berkomunikasi dengan siswa lainnya. Seperti yang diungkapkan oleh Supriyadi (2005) bahwa sebagian besar siswa belum lancar berbicara dalam bahasa Indonesia.

Siswa yang belum lancar berbicara tersebut dapat disertai dengan sikap siswa yang pasif, malas berbicara, sehingga merasa takut salah dan malu, atau bahkan kurang berminat untuk berlatih berbicara di depan kelas. Guru harus mampu menumbuhkan minat berbicara para siswa ketika di dalam kelas khususnya pada kelas IXA. Peserta didik di SMP Negeri 1 Mego berbicara dengan menggunakan bahasa Indonesia masih sangat kurang. Setiap mereka berkomunikasi walaupun di kelas ketika proses pembelajaran, mereka menggunakan bahasa daerah.

Menyampaikan pidato persuasif merupakan materi kelas IXA. semester I sekolah Menengah pertama (SMP), unsur yang akan dinilai adalah siswa mampu mengidentifikasi gagasan, pikiran, pandangan, arahan atau pesan dalam pidato persuasif tentang permasalahan Dan diharapkan pada saat proses pembelajaran baik guru maupun peserta didik terbiasa menggunakan bahasa Indonesia saat berada dilingkungan sekolah dan juga lingkungan formal lainnya.

Berdasarkan uraian di atas, diketahui betapa pentingnya keterampilan berbicara bagi seseorang. Oleh karena itu, pembelajaran keterampilan berbicara perlu mendapat perhatian agar para siswa memiliki keterampilan berbicara. Dengan demikian, ia mampu berkomunikasi untuk menyampaikan isi hatinya kepada orang lain dengan baik. Menurut Nurgiyantoro (2001), ada beberapa bentuk kegiatan berbicara yang dapat dilatihkan untuk mengembangkan keterampilan berbicara siswa. Bentuk-bentuk kegiatan tersebut yaitu wawancara, diskusi, bercerita, dan pidato.

Melalui pembelajaran Kemampuan berbicara bahasa Indonesia dalam menyampaikan pidato persuasif, siswa diharapkan mampu mengungkapkan gagasan, ide, dan pikiran kepada orang lain. Menurut Saksomo (2009) bahwa tujuan berpidato adalah untuk menyampaikan isi hati atau buah pikiran dengan rangkaian kata-kata dengan harapan agar pendengar tergugah hati nuraninya 
dan tergerak pikirannya. Kegiatan berpidato juga mampu menumbuhkan rasa percaya diri untuk berani tampil di depan publik. Keraf (1997: 314) menyebutkan bahwa "peranan pidato, ceramah, penyajian lisan pada suatu kelompok masa merupakan hal yang sangat penting, baik pada waktu sekarang maupun waktu mendatang".

Materi pembelajaran Kemampuan berbicara bahasa Indonesia dalam menyampaikan pidato persuasif diajarkan mulai dari tingkat SMP. Kemampuan berpidato bagi siswa di SMP diharapkan mampu menumbuhkan rasa percaya diri pada anak. Kemampuan berpidato ini perlu dikembangkan dalam dunia pendidikan mengingat dalam bermasyarakat banyak kegiatan yang melibatkan kemampuan ini, misalnya pada kegiatan organisasi, hari-hari besar, dan lain-lain.

Namun, kenyataan berbeda dengan harapan. Kemampuan siswa dalam berpidato masih jauh dari harapan. Keterbatasan wawasan, pengetahuan, dan keingintahuan guru sebagai pelaksana kurikulum belum dapat menvariasikan metode dan teknik pembelajaran yang bertumpu pada PAKEM. Siswa sebagai subjek dianggap sebagai objek sehingga kreativitasnya terbatasi pada suatu teknik yang diatur oleh guru. Sebagai bahan pertimbangan dalam penelitian ini (1) proses pembelajaran berpidato siswa kelas IXA SMP Negeri 1 Mego berbicara tidak kondusif. Selama pembelajaran siswa cenderung pasif; (2) hasil pembelajaran berpidato masih tergolong rendah, masih di bawah kriteria ketuntasan minimal yaitu masih di bawah $65 \%$, sehingga belum mencapai nilai ketuntasan minimal yang ditetapkan yaitu 72 .

Berdasarkan fakta di lapangan, siswa juga sering mengalami kesulitan dalam menguasai keterampilan berbicara. Kesulitan tersebut meliputi faktor kebahasaan yaitu ketepatan ucapan, intonasi (penempatan tekanan, sendi, nada, durasi yang sesuai), diksi dan faktor nonkebahasaan yaitu sikap yang wajar (tenang dan tidak kaku), pandangan kepada lawan bicara, gerak-gerik dan mimik yang tepat, kenyaringan suara, dan kelancaran (penguasaan topik). Kesulitan lain yang dialami siswa adalah masih tidak percaya diri, tidak berani berbicara di depan khalayak, gugup dan salah tingkah ketika berpidato di depan kelas. Hambatan-hambatan tersebut membuat siswa belum menguasai faktor kebahasaan dan faktor nonkebahasaan.

Berdasarkan permasalahan tersebut, maka salah satu upaya yang dapat dilakukan dalam mengoptimalkan kemampuan siswa dalam berpidato yaitu dengan menerapkan teknik pemodelan. Menurut Gabri (2011: 33) "pemodelan 
(modeling) adalah kegiatan pemberian model dengan tujuan agar siswa dapat melihat dan mengamati model yang ditunjukan sehingga dapat mendemonstrasikan model-model yang lain". Untuk membantu konstruksi yang baru siswa harus membentuk pengetahuan mereka sendiri dan guru membantu sebagai mediator dalam proses pembentukan itu.

\section{METODE}

Pada dasarnya bagian ini menjelaskan bagaimana penelitian itu dilakukan. Materi pokok bagian ini adalah: (1) rancangan penelitian; (2) populasi dan sampel (sasaran penelitian); (3) teknik pengumpulan data dan pengembangan instrumen; (4) dan teknik analisis data. Untuk penelitian yang menggunakan alat dan bahan, perlu dituliskan spesifikasi alat dan bahannya.Spesifikasi alat menggambarkan kecanggihan alat yang digunakan sedangkan spesifikasi bahan menggambarkan macam bahan yang digunakan.

Untuk penelitian kualitatif seperti penelitian tindakan kelas, etnografi, fenomenologi, studi kasus, dan lain-lain, perlu ditambahkan kehadiran peneliti, subyekpenelitian, informan yang ikut membantu beserta cara-cara menggali data-data penelitian, lokasi dan lama penelitian serta uraian mengenai pengecekan keabsahan hasil penelitian.

Sebaiknya dihindari pengorganisasian penulisan ke dalam "anak subjudul" pada bagian ini. Namun, jika tidak bisa dihindari, cara penulisannya Model penelitian yang digunakan adalah deskriptif kualitatif. Penelitian ini dilakukan untuk menggambarkan dan mengamati proses belajar siswa Kelas IXA SMP Negeri 1 Mego berbicara dalam berpidato melalui penerapan teknik pemodelan (modeling). Melalui penelitian yang dilakukan oleh guru, diharapkan dapat meningkatkan proses dan hasil pembelajaran.

\section{Variabel Penelitian}

Penelitian ini mengkaji tentang peningkatan kemampuan berpidato melalui teknik pemodelan siswa kelas IXA SMP Negeri 1 Mego. Dengan demikian, variabel yang diteliti yaitu penigkatan kemampuan berbicara bahasa Indonesia dalam menyampaikan pidato persuasif sebagai varibel terikat dan teknik modeling sebagai variabel bebas.

\section{Desain Penelitian}

Penelitian ini direncanakan selama dua pertemuan, setiap pertemuan merupakan rangkaian kegiatan yang saling berkaitan. Apabila pertemuan I 
belum menunjukkan peningkatan kemampuan berbicara bahasa Indonesia dalam penyampaikan pidato, maka akan dilanjutkan ke pertemuan II.

\section{Populasi dan Sampel Penelitian}

Populasi dalam penelitan ini adalah siswa SMP Negeri 1 Mego. Tahun Pelajaran 2018/2019 sebanyak 28 siswa. Sampel yang akan diteliti adalah siswa IXA SMP Negeri 1 Mego dengan jumlah siswa 27 orang.

\section{Teknik Pengumpulan Data}

Teknik pengumpulan data yang akan digunakan dalam penelitian ini terdiri dari instrumen utama dan instrument penunjang. Instrumen utama adalah peneliti sendiri yang memiliki syarat, kemampuan mengumpulkan, menyeleksi, menilai, menyimpulkan dan menentukan data. Adapun instrumen penunjang antara lain; 1) observasi, 2) wawancara, dan 3) dokumentasi. Teknik pengumpulan data dilakukan dengan teknik tes menulis naskah pidato, tes lisan yang berbentuk tes berpidato dan teknik pelengkap berupa lembar pengamatan kegiatan pembelajaran, lembar penilaian dan pendokumentasian secara audio visual (menggunakan kamera digital). Pengambilan data melalui kamera digital dibantu oleh kolaborator.

\section{Teknik Analisis Data}

Data yang terkumpul dari hasil pekerjaan siswa, wawancara dan observasi dianalisis dengan menggunakan teknik analisis data kualititatif. Adapun model analisis yang digunakan menurut Miles dan Huberman terdiri dari 4 komponen kegiatan yaitu: melakuan pengumpulan data, mereduksi data, menyajikan data, dan menarik kesimpulan.

Teknik analisis data terdiri dari analisis penggunaan teknik modeling. Penggunaan teknik modeling dianalisis dengan cara mendeskripsikan data yang diperoleh melalui observasi terhadap guru dan siswa. Sedangkan untuk analisis data hasil diperoleh dengan mendeskripsikan melalui persentase dan skor dalam berbahasa Indonesia melalui pidato persuasif.

\section{PEMBAHASAN}

Penelitian ini dilakukan dalam dua pertemuan. Pertemuan II dilakukan sebagai pelaksanaan tindakan yang merupakan perbaikan pembelajaran dari pertemuan I. Untuk memperoleh hasil penelitian, dilakukan penjaringan data tes dan nontes dengan menggunakan instrumen tes dan nontes, baik pada pertemuan I maupun pertemuan II. Berdasarkan hasil tersebut diketahui taraf peningkatan kemampuan berpiadato siswa dan efektivitas penggunaan teknik 
modeling. Berdasarkan hasil tes kemampuan berpidato siswa melalui teknik modeling diperoleh hasil bahwa jumlah siswa yang memperoleh nilai ketuntasan minimal mengalami peningkatan $40 \%$ dari $43 \%$ pada pertemuan I meningkat menjadi $83 \%$ pada pertemuan II.

Meningkatnya jumlah siswa yang mencapai nilai KKM $43 \%$ pada pertemuan I menjadi 83\% pada pertemuan II ini terjadi akibat adanya perbaikan pada pertemuan II dari refleksi pada pertemuan I. Untuk lebih memantapkan kemampuan berpiadato dengan teknik modeling ini, pada pertemuan II peneliti lebih bersemangat dibandingkan pada pertemuan I. Pada pertemuan I, kemampuan berpidato siswa melalui teknik modeling belum memuaskan dan suasana kelas selama proses pembelajaran berlangsung kurang kondusif dengan adanya siswa yang lebih bergantung pada teman lain dan berbicara sendiri sehingga mengganggu siswa yang lain. Hal ini disebabkan oleh kondisi mental siswa yang belum terbiasa untuk tampil di depan umum atau orang banyak. Kondisi ini juga disebabkan karena siswa kurang paham dan kurang mengerti dengan teknik pembelajaran yang diterapkan. Ketika tampil di depan, masih banyak siswa yang merasa gugup.

Walaupun pada pertemuan I hasil tes siswa kurang memuaskan dan suasana kelas selama proses pembelajaran berlangsung kurang kondusif, namun pada pertemuan kedua kegiatan pembelajaran sudah lebih kondusif. Guru sudah dapat memahami perannya dalam menggunakan teknik modeling. Siswa dalam pembelajaran pertemuan II juga telah mengerti pembelajaran dengan menggunakan teknik modeling. Siswa lebih antusias dan tidak bergantung lagi kepada temannya. Semangat yang ditunjukkan siswa pada pembelajaran pertemuan II sangat baik, semua siswa sangat bersemangat dan penuh kegigihan menjalankan langkah demi langkah pembelajaran yang diberikan oleh guru.

Perubahan itu tidak lepas dari tindakan-tindakan yang peneliti lakukan dan pemberian motivasi kepada siswa guna memperbaiki kekurangankekurangan yang ada serta motivasi kepada siswa guna memahami pentingnya kemampuan berpidato dalam kehidupan sehari-hari. Hal ini peneliti lakukan untuk memotivasi siswa agar mereka sadar dan mau berlatih berpidato dengan bersungguh-sungguh. Dengan motivasi yang tinggi akan lebih mudah bagi siswa menerima dan mengikuti proses pembelajaran. Kondisi pembelajaran yang diwarnai dengan antusias siswa dalam mengikuti proses pembelajaran merupakan bukti bahwa kelas tersebut hidup. Oleh karena nilai rata-rata hasil 
belajar para siswa yang diperoleh telah menunjukkan peningkatan sesuai dengan yang telah ditetapkan.

Berdasarkan analisis situasi, diketahui bahwa kondisi pembelajaran pada pertemuan II lebih menunjukkan pembelajaran yang kondusif. Pada pertemuan II ini siswa lebih antusias mengikuti proses pembelajaran dengan segala tugas yang diberikan oleh guru. Siswa terlihat antusias mengikuti proses berlangsungnya kegiatan dengan ditandai oleh semangat dalam persiapanpersiapan sampai pada saat tampil berpidato di depan teman-temannya. Suasana kelas pun cukup tenang tidak seperti pada pertemuan I, meskipun masih ada siswa yang sibuk sendiri tetapi perhatian siswa hampir semua masih tertuju pada seluruh proses pembelajaran. Terkait dengan teknik yang diberikan, siswa menanggapinya dengan sangat baik. Sebagian besar siswa mengemukakan bahwa adanya teknik modeling dalam pembelajaran dapat memudahkan siswa dalam berpidato. Selanjutnya, wawancara diketahui bahwa siswa merasa kurang percaya diri, gugup atau grogi ketika pertama kali tampil berpidato, sehingga berpengaruh pada nilai berpidatonya.

Tidak mengherankan jika siswa masih merasa kurang percaya diri, gugup atau grogi ketika tampil berpidato. Meskipun hasil tes kemampuan berpidato siswa pada pertemuan I belum termasuk pada kategori baik, namun setidaknya ada upaya berupa usaha siswa guna memperbaiki kesulitan-kesulitan yang ditemui. Kekurangan-kekurangan yang terjadi pada pertemuan I selanjutnya diperbaiki dan ditingkatkan pada pertemuan II. Pada pertemuan II, perencanaan dilakukan dengan lebih matang, sehingga hasil yang dicapai pun menunjukkan peningkatan. Suasana belajar pada pertemuan II ini, lebih kondusif. Siswa senang mengikuti pembelajaran kemampuan berpidato melalui teknik modeling. Siswa sangat antusias mengikuti pembelajaran. Siswa sangat senang mengikuti pembelajaran dengan adanya tontonan video berupa cara berpidato yang baik.

Terkait dengan teknik yang diberikan, siswa menanggapinya dengan sangat baik. Sebagian besar siswa mengemukakan bahwa adanya teknik modeling dalam pembelajaran dapat memudahkan siswa dalam untuk meniru cara berpidato yang baik. Muslich (2007) mengemukakan bahwa melalui teknik model dapat membuat pengajaran menjadi lebih jelas dan konkret dengan adanya model, siswa lebih mudah memahami apa yang dipelajari dengan adanya model daripada hanya diberikan penjelasan, model bisa diperoleh langsung dari yang berkompeten/ahlinya. Pendapat lain dikemukakan oleh Trianto (2010) bahwa teknik modeling membuat siswa meniru perilaku yang 
dimodelkan atau terampil melakukan kegiatan berpidato seperti yang dimodelkan. Dengan demikian, melalui pemodelan siswa memiliki potensi untuk menirukan perilaku yang ditampilkan dengan penuh percaya diri.

Hasil kemampuan berpidato siswa melalui teknik modeling meningkat. Siswa menunjukkan perubahan perilaku ke arah posistif selama mengikuti proses pembelajaran, sehingga suasana pembelajaran lebih kondusif. Berdasarkan serangkaian analisis instrumen penjaring data, diperoleh hasil bahwa ada kesinambungan antara data yang satu dengan data yang lain, baik data tes maupun nontes, guna mengungkap peningkatan kemampuan berpidato dan efektivitas penggunaan teknik modeling.

Berdasarkan hasil analisis diketahui bahwa teknik modeling efektif digunakan dalam pembelajaran berpidato dengan memberikan tema kegiatan seputar dunia siswa yang dekat dengan kehidupan mereka di sekolah. Penelitian tindakan kelas yang peneliti lakukan ini mampu menunjukkan peningkatan nilai rata-rata yang diperoleh siswa. Oleh karena itu, penelitian ini dianggap berhasil dan tidak perlu diulang pada pertemuan berikutnya.

\section{KESIMPULAN}

Berdasarkan analisis data dan pembahasan, dapat disimpulkan bahwa penerapan teknik modeling dapat meningkatkan proses dan hasil pembelajaran tentang kemampuan berpidato siswa kelas IXA SMP Negeri 1 Mego. Pada proses pelaksanaan pembelajaran siswa lebih bersemangat dan sangat antusias dalam berpidato dengan teknik modeling. Peningkatan itu terlihat dari aktivitas siswa dan aktivitas guru dalam pembelajaran berpidato. Peningkatan proses pembelajaran berpidato meliputi seluruh kemampuan kebahasaan yang terdiri dari aspek ketepatan ucapan, intonasi, pilihan kata, dan kemampuan nonkebahasaan yang terdiri dari aspek sikap wajar, pandangan, mimik/gerak-gerik, kenyaringan suara, kelancaran. Peningkatan itu terlihat dari peningkatan nilai rata-rata dari pertemuan I ke pertemuan II.

Penerapan teknik modeling telah memberikan efek peningkatan pada hasil belajar siswa pada setiap pertemuan. Hal ini terlihat dari peningkatan persentase ketuntasan siswa dari pertemuan I hingga pertemuan II. Pada pertemuan I, siswa yang abelum tuntas $57 \%$ dan yang tuntas $43 \%$ dengan nilai rata-rata kemampuan berpidato siswa 66,8 dengan kategori cukup mampu. Pada pertemuan II, siswa yang belum tuntas $17 \%$ dan yang tuntas $83 \%$ dengan nilai rata-rata kemampuan berpidato siswa adalah 84,4 dengan kategori mampu. Hasil 
ini telah mencapai persentase target keberhasilan yang telah ditentukan peneliti sebelum penelitian dilakukan yaitu $80 \%$.

\section{DAFTAR PUSTAKA}

Ahmad. 2006. Kamus Besar Bahasa Indonesia. Jakarta: Reality Publisher.

Arsjad, Maidar G. dan U. S. Mukti. 1998. Pembinaan Kemampuan Berbicara Bahasa Indonesia. IKIP Jakarta: Erlangga.

Bandiyah. 2013. Peningkatan Kemampuan Berpidato Melalui Teknik Pemodelan Siswa Kelas IX-C SMP Negeri 1 Singosari Kabupaten Malang Tahun Pelajaran 2012/2013. Tesis. Tidak diterbitkan. Malang: Universitas Negeri Malang.

Depdikbud RI, Pusat Pembinaan dan Pembinaan Bahasa. 2005. Pedoman Umum Ejaan Bahasa Indonesia yang Disempurnakan dan Pedoman Umum Pembentukan Istilah. Bandung: Pustaka Setia.

Dipodjojo. 2027. Retorika Bertutur Efektif. Jawa Timur: Asri Press

Gabri. 2011. Seni Pidato. Yogyakarta: Cemerlang Publising.

Karomani. 2011. Keterampilan Berbicara 2. Ciputat Tangerang Selatan:Matabaca Publishing.

Kemmis, R. 1992. The Action Research Planner. Victoria: Deaking University.

Keraf, Gorys. 1994. Komposisi. Ende-Flores: Nusa Indah.

Khalik, Abdul.2009. Pengajaran Bahasa di Sekolah Dasar. Makassar ; PGSD FIP UNM.

Marten. 2012. Optimalisasi Pembelajaran Keterampilan Berpidato melalui Strategi Modeling Bagi Siswa Kelas IX SMP Negeri 1 Kulawi. Tesis. :Diterbitkan di Jurnal Kreatif Tadulako (Online Vol. 2 No. 3).

Muslich, Masnur. 2007. KTSP Pembelajaran Berbasis Kompetensi dan Kontekstual. Jakarta: Bumi Aksara.

Nio, Be Kim Hoa. 2008. Percakapan dan Diskusi. Jakarta: P3G Depdikbud.

Nurgiyantoro, Burhan. 2001. Penilaian dalam Pengajaran dan Sastra. Yogjakarta: BFE.

Nurhadi. 2012. Panduan Pidato Luar Biasa. Yogyakarta: Mega Books.

PPS UNM. 2012.Pedoman Penulisan Tesis dan Disertasi. Makassar: PPS UNM.

Saksomo, Dwi. 2009. Berbicara Monologis (Wicara Individual). Malang: Universitas Negeri Malang.

Syafii. 1994. Retorika dalam Menulis. Jakarta: Depdikbud. 
Simon. 2005. Dasar-Dasar Keterampilan Berbahasa Indonesia. Surakarta: UNS Press.

Tarigan, Henry Guntur. 2008. Berbicara Sebagai Salah Satu Keterampilan Berbahasa. Bandung: Angkasa.

Trianto. 2010. Mendesain Model Pembelajaran Inovatif Progresif. Jakarta: Kencana.

Wibowo. 2014. Strategi Belajar Mengajar. Bandar Lampung: FKIP Unila.

Willis, Sofyan S. 2004. Konseling Individual teori dan praktek. Bandung : Alfabeta.

Wiyanto, Asul. 2009. Belajar Berpidato untuk Pemula. Semarang: Aneka Ilmu 